University of Nebraska - Lincoln

DigitalCommons@University of Nebraska - Lincoln

10-1979

\title{
Inflorescence Architecture and Flower sex Ratios in Sagittaria brevirostra (Alismataceae)
}

Robert B. Kaul

University of Nebraska-Lincoln

Follow this and additional works at: https://digitalcommons.unl.edu/bioscifacpub

Part of the Biology Commons, and the Botany Commons

Kaul, Robert B., "Inflorescence Architecture and Flower sex Ratios in Sagittaria brevirostra (Alismataceae)" (1979). Faculty Publications in the Biological Sciences. 855.

https://digitalcommons.unl.edu/bioscifacpub/855

This Article is brought to you for free and open access by the Papers in the Biological Sciences at DigitalCommons@University of Nebraska - Lincoln. It has been accepted for inclusion in Faculty Publications in the Biological Sciences by an authorized administrator of DigitalCommons@University of Nebraska - Lincoln. 
KAUL IN AMERICAN JOURNAL OF BOTANY (OCTOBER 1979) 66(9): 1,062-1,066.

COPYRIGHT 1979, WILEY. USED BY PERMISSION.

\title{
Inflorescence Architecture and Flower sex Ratios in Sagittaria brevirostra (Alismataceae)
}

\author{
Robert B. Kaul \\ School of Life Sciences, University of Nebraska, Lincoln, Nebraska, USA
}

\begin{abstract}
Two populations of Sagittaria brevirostra from the same lake were sampled 10 years apart and yielded similar data on inflorescence structure and on numbers and ratios of male and female flowers. Larger inflorescences have relatively more male than female flowers than do smaller inflorescences. Pollination success is unrelated to inflorescence size or sex ratio within an inflorescence.
\end{abstract}

In monoecious and dioecious plants the male and female gametes are produced in separate flowers and successful sexual reproduction depends upon synchronous flowering of staminate (male) and pistillate (female) flowers, at least within the reproducing population if not within the individual plant. Monoecious species can be functionally dioecious if there is strong asynchrony of flowering of the sexes.

One measure of the reproductive capacity of monoecious plants is the ratio of male to female flowers produced. Although the number of male gametes produced ordinarily vastly exceeds the number of female gametes, irrespective of the distribution of the sexes on individuals or within populations, the ratios of male to female flowers do not necessarily reflect this disproportionate gametic ratio. More important are sex ratios of the flowers themselves because they are the functional units in attracting pollinators in most nonpseudanthial plants. Most monoecious and dioecious species probably produce more male than female flowers, and over a longer period too, thus maximizing the opportunities for pollination.

This study reports data on inflorescence architecture and sex ratios of flowers in a population of the monoecious aquatic perennial Sagittaria brevirostra Mack. and Bush in 1967, and compares them with results found in an identical study done at the same lake 10 years later.

\section{Materials and Methods}

In 1967, and again in 1977, 100 inflorescences were sampled along a $100-\mathrm{m}$ transect at Conestoga Lake near Lincoln, Nebraska. The 1967 sample was from the only population of the species in the lake at the time. By 1977 the 1967 site had been overrun by grasses so another site from another bay was chosen.

Conestoga Lake is an artificial impoundment which filled in 1964. Its waters have steadily eutrophicated by runoff from the fertile soils near-by, and it has become quite alkaline (cf. Hergenrader and Hammer,
1973). The growth of aquatic plants in the lake has been considerable, and by 1977 S. brevirostra had come to occupy large areas on mud flats and in shallow water of sheltered bays all around the lake.

There is much variation in water level during the year. It is high in spring and ordinarily drops $1 \mathrm{~m}$ or more in autumn, but sometimes, after heavy summer storms, the water rises quickly. During the unusually dry summers of 1974-1976 the lake remained at very low levels and the beds of Sagittaria that grew in early summer withered and did not flower in late summer. Thus the 1977 sampling was done in the first year of recovery after the drought.

The inflorescences were analyzed for number of branches, number of flowers per inflorescence and per branch, numbers of male and female flowers, and distribution of the flower sexes.

\section{Results}

Sagittaria brevirostra is a robust, emergent perennial of muddy shores which flowers in late summer and which produces clones by forming tubers at the ends of rhizomes in autumn. Each ramet of the clone ordinarily pro- duces one inflorescence having $1,2,3$, or no branches (Figures 1-4).

Flowers are produced in pseudowhorls of 3 (cf. Charlton, 1973). The female flowers are borne at the proximal few nodes of the main axis and branches, while the usually more numerous male flowers are produced at the more distal nodes (Figures 1-4). Where 1 or 2 branches are borne at the proximal node, the whorl is completed with 2 or 1 female flowers, respectively (Figures 2 and 3). No branches are produced above the lowest node. In almost half of the main axes examined there is a mixed-sex whorl between the lower female whorls and upper male whorls (Figure 4). In the 1967 sample all inflorescences had both male and female flowers, but in the 1977 sample 2 inflorescences had only female flowers and 3 


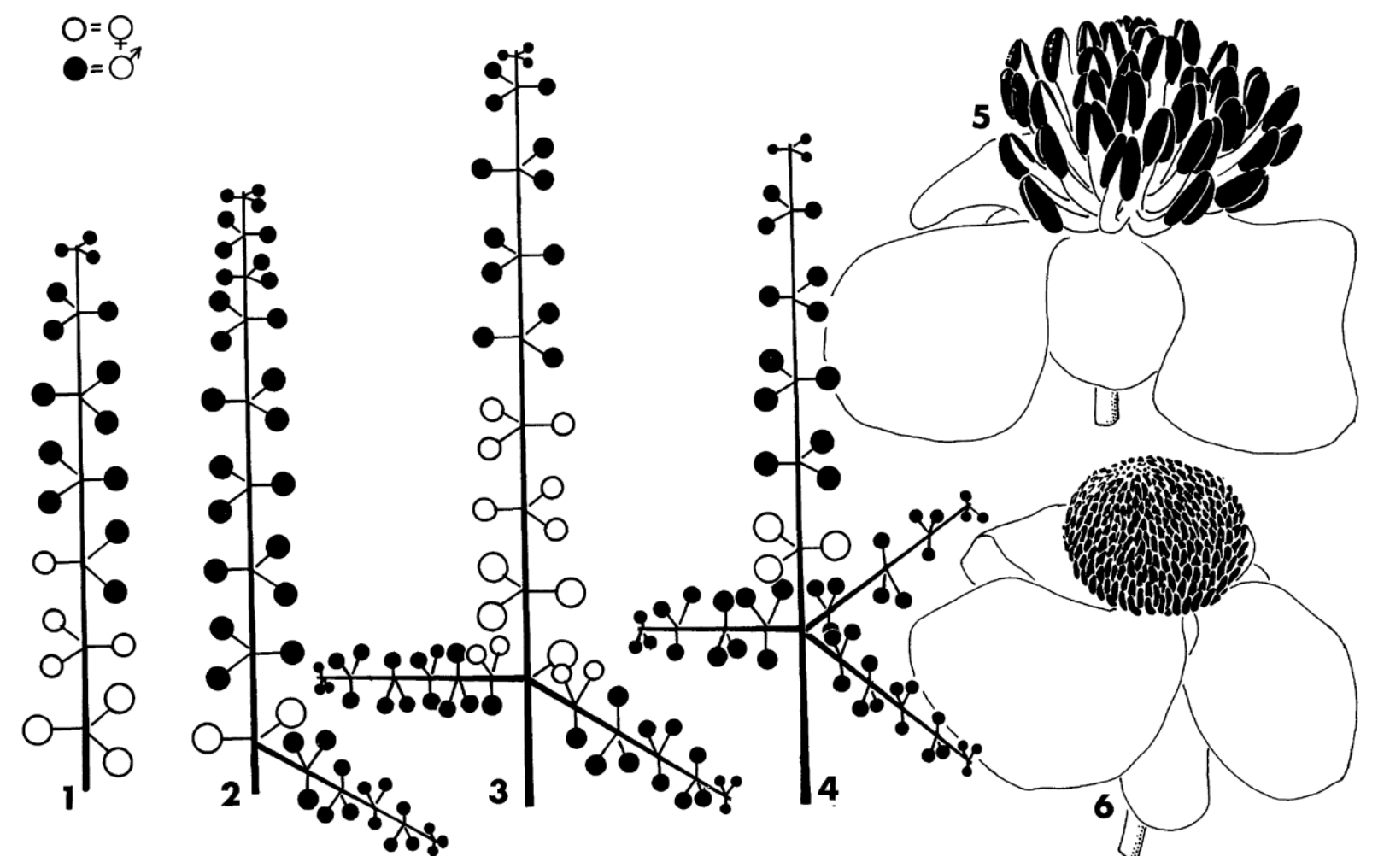

Figures 1-4. Some representative patterns of distribution of flower sexes and branching. | Figure 5. Male flower. x2.5. | Figure 6. Female flower. $\times 2.5$.

had only males. Of the 10,607 flowers examined in both samples only one was perfect.

Flowering is acropetal, with the females opening first in rapid succession within the whorls and acropetally on the axes, and the males opening after the first females open and continuing to open long after the females on the inflorescence have shed their petals and become non-receptive. Pollination is probably both geitonogamous and xenogamous.

The male and female flowers are of similar size (Figures 5 and 6) and color, the females with white petals and hundreds of tiny yellow carpels densely crowded on the globose receptacle, and the males with white petals and 24-54 yellow-anthered stamens. The more distal flowers of both sexes tend to be somewhat smaller than the proximal ones.

Table 1. Flowers produced in 1967 and 1977, all inflorescences combineda $^{a}$

\begin{tabular}{lllll}
\hline Year & Sex & Total & Mean/infl. & $\begin{array}{l}\text { Standard } \\
\text { deviation }\end{array}$ \\
\hline 1967 & $\mathrm{f}$ & 1,244 & 12.44 & 5.13 \\
1977 & $\mathrm{f}$ & 1,168 & 11.68 & 5.00 \\
1967 & $\mathrm{~m}$ & 4,406 & 44.06 & 15.26 \\
1977 & $\mathrm{~m}$ & 3,789 & 37.89 & 15.94 \\
\hline
\end{tabular}

a Differences not significant; $F$ test, $P=.05$.
After pollination the corolla of the female flowers falls away and the calyx remains reflexed while the receptacle enlarges and accommodates the ripening achenes, which turn green soon after pollination. The male flowers wither and fall after anthesis, leaving bare the axes above the ripening fruits.

The total number of flowers produced in the 1967 sample was 5,650, and in 1977 it was 4,957. In 1967 there were 1,244 female flowers and 4,406 male flowers; in 1977 there were 1,168 females and 3,789 males. The ratios of males to females in the samples were 3.54 in 1967 and 3.24 in 1977, but the correlation coefficients between numbers of males and females on individual inflorescences were only $r=.23$ in 1967 and $r=.24$ in 1977 ( $n=100$ in both years). The distributions of the sexes are shown graphically in Figure 7A and the statistics are given in Table 1.

When inflorescences are analyzed according to their branching patterns, further similarities be- tween the two samples appear. The distribution of branching patterns was much the same in the samples of both years, with strong tendencies for multiple branching (Figure 7F). Table 2 gives statistics for the frequencies of male and female flowers in both years according to the four categories of branching $(0,1,2,3$ branches). The more branches in an inflorescence the more flowers it is likely to have, but this increase is dispropor- 


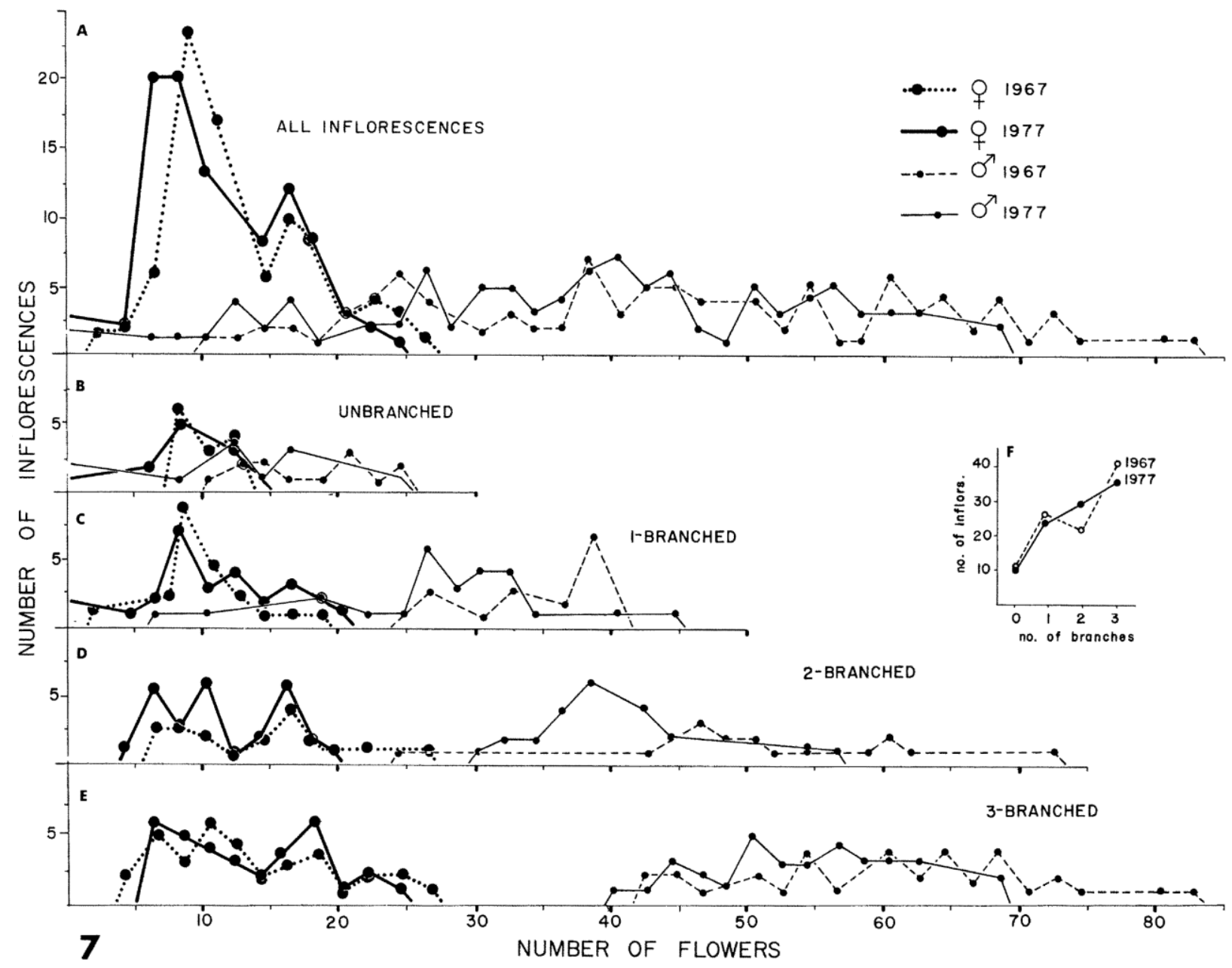

Figure 7. Distributions of male and female flowers in inflorescences in 1967 and 1977.

tional between the sexes. While there is less than a 2fold increase in the number of female flowers from unbranched through 3- branched inflorescences, the increase in male flowers is 3 -fold. This pattern appears in both the 1967 and the 1977 samples (Figure 7B-E).

Further analysis of the distribution of flower numbers and sexes by branching patterns shows that the increase in number of male flowers with increase in number of branches is largely brought about by an increase in numbers of male flowers occurring upon the branches and not upon the main axes. Table 3 shows that numbers of male and female flowers on the main axes were similarly distributed in both years sampled. It also shows that there is no increase in female flowers on the main axes with increase in number of branches, and that there is barely any change in the number of male flowers in the main axes either.

Table 2. Total flowers per inflorescence, by branching pattern (mean and standard deviation)a

\begin{tabular}{|c|c|c|c|c|c|c|c|c|c|}
\hline Year & Sex & \multicolumn{2}{|c|}{ Unbranched } & \multicolumn{2}{|c|}{ 1-branched } & \multicolumn{2}{|c|}{ 2-branched } & \multicolumn{2}{|c|}{ 3-branched } \\
\hline 1967 & $\mathrm{f}$ & 10.38 & 1.71 & 9.76 & 3.77 & 14.25 & 5.79 & 13.38 & 5.47 \\
\hline 1977 & $\mathrm{f}$ & 9.70 & 2.37 & 10.20 & 4.81 & 11.61 & 4.45 & 13.68 & 6.03 \\
\hline 1967 & $\mathrm{~m}$ & 17.92 & 4.68 & 33.81 & 5.45 & 50.77 & 10.44 & 60.80 & 10.37 \\
\hline 1977 & $\mathrm{~m}$ & 11.18 & 6.05 & 27.36 & 8.16 & 39.78 & 5.77 & 54.15 & 6.94 \\
\hline
\end{tabular}

a Differences not significant $(F$ test, $P=.05)$ except $\left({ }^{*}\right)$. 
Table 3. Flowers produced on the main axis of the inflorescence (mean and standard deviation)a

\begin{tabular}{|c|c|c|c|c|c|c|c|c|c|c|c|}
\hline \multirow{2}{*}{$\begin{array}{c}\text { Year } \\
1967\end{array}$} & \multirow{2}{*}{$\begin{array}{ll} & \text { Sex } \\
\mathrm{f} & \end{array}$} & \multicolumn{2}{|c|}{$\begin{array}{l}\text { All inflorescences } \\
\text { combined }\end{array}$} & \multicolumn{2}{|c|}{ Unbranched } & \multicolumn{2}{|c|}{ 1-branched } & \multicolumn{2}{|c|}{ 2-branched } & \multicolumn{2}{|c|}{ 3-branched } \\
\hline & & 9.84 & 3.16 & 10.38 & 1.71 & 9.46 & 3.09 & 11.00 & 3.14 & 11.05 & 2.88 \\
\hline 1977 & $\mathrm{f}$ & 8.78 & 3.09 & 9.70 & 2.37 & 9.35 & 4.11 & 9.59 & 2.69 & 9.79 & 2.43 \\
\hline 1967 & $\mathrm{~m}$ & 19.26 & 4.71 & 17.92 & 4.68 & 20.04 & 3.38 & 20.26 & 4.28 & 19.24 & 5.10 \\
\hline 1977 & $\mathrm{~m}$ & 16.40 & 4.43 & 11.18 & 6.05 & 17.30 & 5.56 & 16.25 & 3.55 & 17.06 & 2.83 \\
\hline 1967 & $\mathrm{f} \& \mathrm{~m}$ & 29.53 & 4.68 & & & & & & & & \\
\hline 1977 & $\mathrm{f} \& \mathrm{~m}$ & 25.09 & 4.43 & & & & & & & & \\
\hline
\end{tabular}

a Differences not significant $(F$ test, $P=.05)$ except $\left(^{*}\right)$.

When the flowers produced on the branches alone are compared, strong similarities between the samples appear (Table 4). The more branch- es, the more female flowers likely to be found upon them, even though very few female flowers occur on branches at all. The number of flowers on branches increases 3-4-fold with increase from 1 to 3 branches, but the total ratios of males to females on the entire inflorescences are then changed to favor heavily the male flowers.

\section{Discussion}

The numerous similarities in in- florescence structure and sex ratios of the flowers found in both years sampled show the constancy of variation in these phenomena for the species in this area. Preliminary data from near- by lakes support this conclusion. If other components of reproductive capacity are also similar, then it is likely that there is a constant reproductive effort by the population in each good flowering year. There are no apparent effects of eutrophication upon flowering, nor are there effects of drought-induced non-flowering years upon subsequent years' flowering capacity. Wooten (1971) also found constancy of flower sex under different environmental conditions for $\mathrm{S}$. latifolia.

The 1977 population is probably descended from the 1967 one, which was the only one in the lake at the time, but whether it is a clonal or seed descendant is unknown. Either is possible because the achenes float for a time and germination is delayed (Kaul, 1978), and there is vegetative mobility because living tubers sometimes break from the rhizomes in autumn and float to quiet bays, where they quickly re-establish.

Increasing inflorescence size results in increased "maleness" by the production of even greater ratios of male to female flowers than in smaller inflorescences. This can be viewed as the least energetically expensive way to maximize reproductive potential because of the short life and lesser energy demands of the male flowers relative to the females.

Because virtually all female flowers produce heavy fruit crops, irrespective of the size of inflorescence which bears them, I conclude that inflorescence size and sex ratio within an inflorescence have no effects upon pollination success. Other factors are undoubtedly at work, but so little is known of pollination in the genus that further conclusions are premature.

The flowers of S. brevirostra swarm with small insects, at least some of which are surely pollinators. Robertson (1929) observed 66 species of insects in four orders visiting both male and female flowers of S. latifolia in Illinois. This large number of visitors and the changing sex ratios of flowers in anthesis throughout the flowering season indicate that the pollination syndrome is a complicated one.

Table 4. Flowers produced on the branches of the inflorescences (mean and standard deviation)a

\begin{tabular}{|c|c|c|c|c|c|c|c|c|c|}
\hline \multirow{2}{*}{$\begin{array}{l}\text { Year } \\
1967\end{array}$} & \multirow{2}{*}{ Sex } & \multicolumn{2}{|c|}{$\begin{array}{c}\text { All branched } \\
\text { inflorescences }\end{array}$} & \multicolumn{2}{|c|}{ 1-branched } & \multicolumn{2}{|c|}{ 2-branched } & \multicolumn{2}{|c|}{ 3-branched } \\
\hline & & 0.96 & 3.16 & 0.25 & & 1.66 & & 3.30 & \\
\hline 1977 & $\mathrm{f}$ & 0.99 & 3.09 & 0.65 & & 1.74 & & 3.64 & \\
\hline 1967 & $\mathrm{~m}$ & 12.98 & 4.09 & 13.17 & 2.68 & 26.00 & 6.65 & 38.82 & 10.97 \\
\hline 1977 & $\mathrm{~m}$ & 12.03 & $2.85^{*}$ & 10.09 & 4.31 & 23.85 & $3.77^{*}$ & 38.38 & $5.87^{*}$ \\
\hline 1967 & $\mathrm{f} \& \mathrm{~m}$ & 13.92 & 4.39 & & & & & & \\
\hline 1977 & $\mathrm{f} \& \mathrm{~m}$ & 13.48 & $2.99 *$ & & & & & & \\
\hline
\end{tabular}

a Differences not significant $(F$ test, $P=.05)$ except $\left(^{*}\right)$. 


\section{Literature Cited}

Charlton, W. A. 1973. Studies in the Alismataceae. II. Inflorescences of Alismataceae. Canadian Journal of Botany 51: 775-789.

Hergenrader, G. L., and M. J. Hammer. 1973. Eutrophication of small reservoirs in the Great Plains. Geophysical Monographs Series, volume 17: 560-566.
Kaul, R. B. 1978. Morphology of germination and establishment of aquatic seedlings in Alismataceae and Hydrocharitaceae. Aquatic Botany 5: 139-147.

Robertson, C. 1929. Flowers and insects. Science Press, Lancaster, Pennsylvania, USA.

Wooten, J. W. 1971. The monoecious and dioecious conditions in Sagittaria latifolia L. (Alismataceae). Evolution 25: 549-553. 